\title{
Histology of Watersnake (Enhydris enhydris) Lung
}

\author{
Zainuddin Zainuddin ${ }^{1 *}$, Nurul Fadhilah ${ }^{2}$, Dian Masyitha ${ }^{1}$, Muhammad N. Salim ${ }^{3}$ Erdiansyah Rahmi $^{1}$, Fadli A. Gani $^{4}$, \\ and Muhammad Jalaluddin ${ }^{4}$

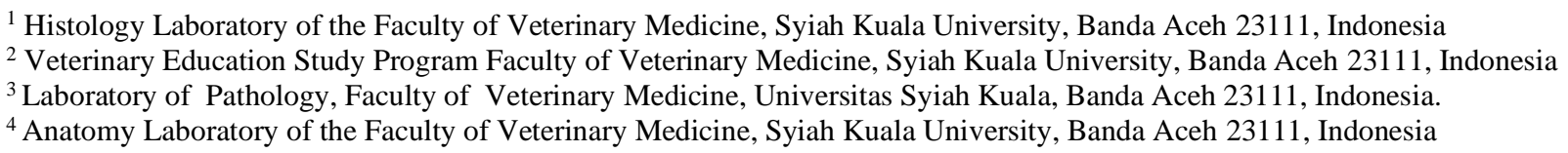

\begin{abstract}
Rainbow watersnake is a snake that can be found in ponds, has a relatively medium body, a maximum length of $80 \mathrm{~cm}$, generally between $50-60 \mathrm{~cm}$, small-headed, a rather large belly, and short-tailed. The aim of this study is to determine the structure of the histology of the lungs of watersnake (Enhydris enhydris). This study used a sample of 3 watersnakes (Enhydris enhydris) with a body length of $\pm 50 \mathrm{~cm}$. This study conducted a micro technical method with hematoxylin-eosin (HE) staining. Data obtained from the results of this study were analyzed descriptively and presented in the form of images. Macroscopic observations of the warp in snakes are long, most of the trachea attaches to the warp, and there are water sacs or swimming pouches at the tip of the warp, as well as the histological features of the snakes' warp, alveolar ducts, alveolar sac and alveoli, the histological structure of the lungs in watersnakes (Enhydris enhydris) consist of type 1 alveoli epithelial cells, type 2 alveoli cells, muscle bundles, connective tissue, capillary vessels, and macrophage cells. Based on the results of the study, it can be concluded that the histological structure of the watersnake (Enhydris enhydris) lung is different from the histological structure of the reptile function in general. In the lungs of watersnakes (Enhydris enhydris) only consists of alveolar ducts, alveolar sacs, alveoli, and the presence of water sacs at the ends of the lungs.
\end{abstract}

Keywords: Watersnake (Enhydris enhydris), Histology, Lungs.

\section{Introduction}

Reptiles are reptiles, are one class of vertebrate animals and are cold-blooded or poikilothermal animals, meaning that the body temperature of these animals depends on the temperature of the environment, therefore this class of animals is more commonly found in tropical and subtropical regions. The animal's body is covered by dry and scaly skin, this animal also breathes using the lungs [1]. Noted 511 types of reptiles live in Indonesia and are grouped in 4 orders, where one of the orders is Squamata which includes three suborders. Sarpentes (snake) is one of the suborders of the order Squamata, one example of this suborder is the rainbow water snake [2].

One of the snakes found in the pond is a rainbow water snake. The rainbow water snake has a relatively medium body, a maximum length of $80 \mathrm{~cm}$, generally between 50-60 cm, small-headed, rather a large belly, and short-tailed. The back (dorsal) is generally light brown to blackish gray. The lower side of the body (lateral) is bright yellow or whitish. The underside of the body (ventral) is yellowish or whitish, sometimes with faint spots or lines along its midline [3]. These rainbow water snakes are widespread ranging from Pakistan and Nepal, India, Bangladesh, Burma, Laos, Vietnam, Cambodia, Thailand, and Indonesia. In the morning and afternoon, the snake often removes its head and part of its body from the water and is silent to breathe. In villages on the island of Java children often play with these snakes, because these snakes are generally benign and do not want to bite [4].

Breathing (respiration) is the event of breathing air from outside which contains (oxygen) and exhales air that contains carbon dioxide as a residual from oxidation out of the body. Inhalation is called inspiration and exhalation is called expiration [5]. Animals in the reptile class (snakes, lizards, and turtles) generally breathe using the lungs [2].

Lung histology studies have been previously reported [6] on green lizards (Lacerta viridis) [6], black mamba snakes (Dendroaspis polylepis) [7], buhu snakes (Homalopsis bucata) and wood snakes (Ptyas korros) [8]. However, the histology study of lung water of the rainbow snake (Enhydris enhydris) has never been reported, therefore this research is very necessary to complete the information about the histology study of the lung water of the rainbow snake (Enhydris enhydris).

\section{Materials and Methods}

\subsection{Materials}

The tools used are measuring cup, organ storage container, minor surgery set, petri dish, tissue paper, 
staining jar, dropper, volume pipette, $60 \mathrm{oC}$ incubator, embedding processor, microtome, microtome knife, glass object, glass cover, label paper, $37^{\circ} \mathrm{C}$ slide warmer, water bath, light microscope (Olympus CX31) and microscope equipped with a camera (Olympus BX41).

The ingredients used are snake lungs (Enhydris enhydris), physiological NaCL solution $0.9 \%$, neutral buffered formalin (NBF) $10 \%$ as a fixative solution, distilled water, silol, alcohol with multilevel concentrations $(70 \%, 80 \%, 90 \%, 95 \%$, and absolute), paraffin, hematoxylin-eosin (HE) dyes, and Entellan ${ }^{\circledR}$ adhesives.

\subsection{Methods}

This research is an exploratory study to determine the histological structure of the lungs, especially the water snake (Enhydris enhydris). Samples were collected from 3 water snakes (Enhydris enhydris) obtained in the rice fields and ditches around Blang Bintang, Aceh Besar. Samples were then processed by the Kiernan method (1990) into histological preparations with hematoxylineosin (HE).

\subsection{Research Procedure}

\subsubsection{Intake of the lungs}

Samples were taken from three water snakes (Enhydris enhydris) obtained from rice fields and ditches around Blang Bintang, Aceh Besar. Then the snake is anesthetized using clove oil after the snake has anesthetized the lung is taken. Sample preparation is done by removing all organs in the thoracic cavity and taking the lungs along the $3 \mathrm{~cm}$ in the middle. Then the parts of the lungs are rinsed with $0.9 \%$ physiological $\mathrm{NaCl}$ solution until clean, then all parts of the lungs that have been taken apart and spread on mica paper, then put in a fixative solution Neutral Buffered Formalin (NBF) $10 \%$ for 48 hours. Each sample is labeled and then transferred to a $70 \%$ alcohol solution as a stopping point until the dehydration process is carried out.

\subsubsection{Preparation of histological preparations}

The preparation of lung histology preparations refers to the modified Kiernan (1990) method. The process begins with tissue dehydration using a multilevel concentration alcohol solution $(80 \%, 90 \%, 95 \%$, absolute I and absolute II), purification with silol solution, tissue infiltration in paraffin, infiltration of three replications, and continued with planting (embedding) in liquid paraffin until it becomes a paraffin block (blocking). The tissue block is sliced (sectioning) using a microtome with a thickness of $5 \mu \mathrm{m}$ and then the incision is placed in a tissue bath, then taken with a glass object to be incubated into a slide warmer.

\subsubsection{Hematoxylin-eosin staining}

The coloring begins with the deparaffinization process using silol I for 5 minutes and silol II for 2 minutes. Then proceed with the rehydration process with alcohol decreases from absolute alcohol I and II, alcohol 96\% I and II, alcohol $90 \%$ each for 2 minutes, then the tissue slides are put into running water. The next process is to soak the tissue slides in a hematoxylin solution for 5 minutes, then put the tissue slides into running water. After that, the tissue slide is dipped in acid alcohol once dipped and then put water. The tissue slides are then put into the eosin solution for 5 minutes. Then do the dehydration process again with $96 \%$ alcohol I and II, absolute I and II twice each dip. After that the clearing process was carried out with silol I, II, and III for 3 minutes each, then mounting with Entellan ${ }^{\circledR}$. Observations were made with an Olympus light microscope and continued with micrograph photo-taking (Kiernan, 1990).

\subsection{Research Parameters}

The parameters observed in this study were the parts contained in the lungs, namely the bronchi, bronchioles, alveolar ducts, and alveolar saccus.

\subsection{Data analysis}

Data obtained from the results of this study were analyzed descriptively and presented in the form of images.

\section{Results and Discussion}

The results of observations of the structure of the water snake lung (Enhydris enhydris) macroscopically consist of lungs that are attached to a part of the trachea and there is a thin membrane resembling air sacs or swimming sacs that are connected directly to the tip of the lungs of water snakes. The histological structure of the water snake lung (Enhydris enhydris) is composed of alveolar ducts, alveolar sacs, and alveoli. Where alveolar ducts, alveolar sacs, and alveoli are composed of alveoli type 1 epithelial cells, type 2 alveoli epithelial cells, muscle bundles, connective tissue, capillaries, and dust cells. In the water snake (Enhydris enhydris) the trachea is directly adjacent to the alveolar duct and the alveolar space is wider (Figure 1), whereas in mammals and aves have intrapulmonary bronchi, terminal bronchi and respiratory bronchi are more indirect so the trachea borders on the alveoli and the space between the alveoli and intrapulmonary bronchi. meetings [9].

Thin membranes resembling air sacs or swimming sacs in fish have two gas sacs, have flexible walls that contract and develop based on maximum air pressure. The air bubble wall has few blood vessels and is coated by guanine crystals which makes it airtight and makes it complex and flexible. The airbag has a function as control of buoyancy, to be able to save energy for swimming. Another function of air bubbles is to be used as a resonating space for producing or receiving sounds, but also as a respiratory organ in physostome animals [10]. 


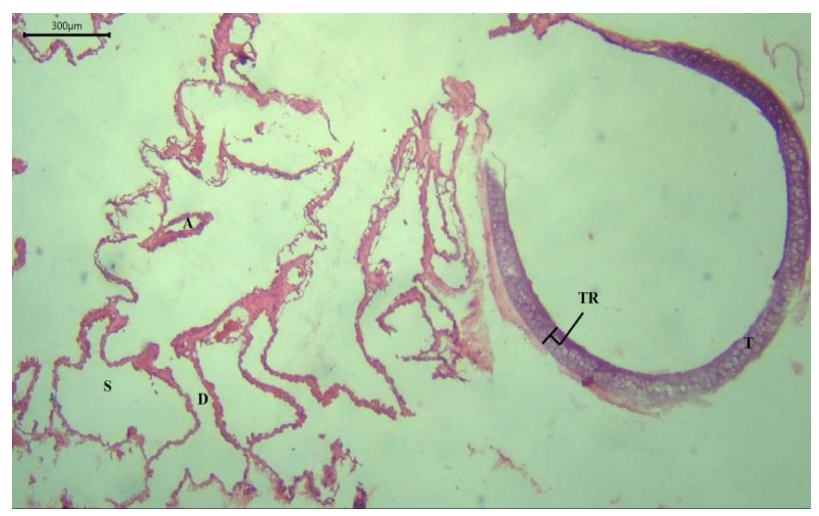

Figure 1. Histological structure of the water snake (Enhydris enhydris) lung. $\mathrm{D}=$ alveolar duct, $\mathrm{S}=$ alveolar sac, $\mathrm{A}=$ Alvoli, $\mathrm{TR}=$ Cartilage, $\mathrm{T}=$ Trachea. Magnification of $40 \mathrm{X}$.

Type 1 alveoli cells, also called type 1 pneumocyte cells, are a very thin layer of flat cells lining the alveoli in the lungs. These type 1 alveoli cells come into direct contact with the capillary endothelial layer, forming the blood barrier. Alveoli type 2 epithelial cells which are also called pneumocyte type 2 cells or sepalis cells, the number of epithelial cells is less than the type 2 alveoli epithelial cells and cuboid shaped. These epithelial cells also produce phospholipid-rich products, surfactants. Surfactants released by these epithelial cells will coat the alveoli type 1 epithelial cells and will reduce the surface tension of the alveoli to prevent the collapse of the alveoli during inspiration [11].

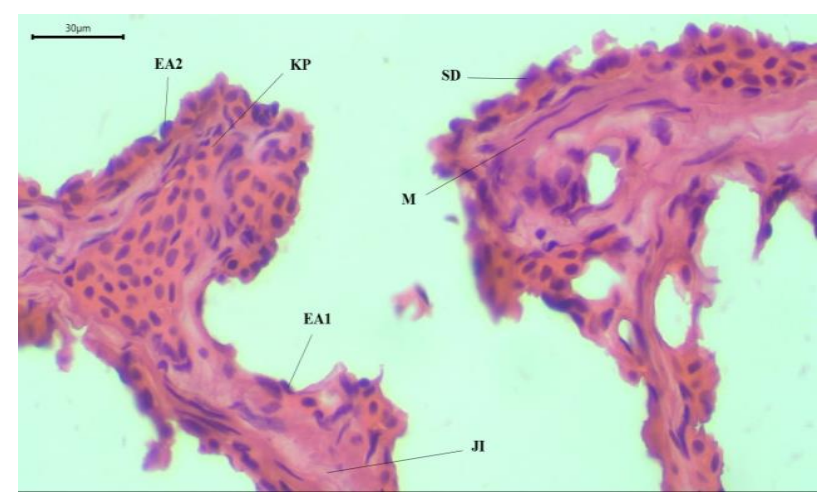

Figure 2. Alveolar duct boundary structure in the lungs of water snakes (Enhydris enhydris). EA1 = type 1 alveoli epithelial cells, $\mathrm{EA} 2$ = type 2 epithelial cells, $\mathrm{M}=$ muscle, $\mathrm{JI}=$ connective tissue, $\mathrm{PK}=$ Capillary vessels, $\mathrm{SD}=$ dust cells. Magnification of 400 $\mathrm{X}$.

In alveolar ducts, many alveoli coincide so that the duct boundaries only appear in the form of thickening of the free edge of intralveoli. The thickened adluminal edge of the intralveoli septa is covered by bronchial epithelial cells over smooth bundles of smooth muscle in the septa connective tissue [12] (Figure 2). From the results of observations on the ductus, there were type 1 alveolus epithelial cells and type 2 alveoli epithelial cells, collagen and elastin connective tissue, and smooth muscle bundles on thickening of the intralveoli septa edge (Figure 3).

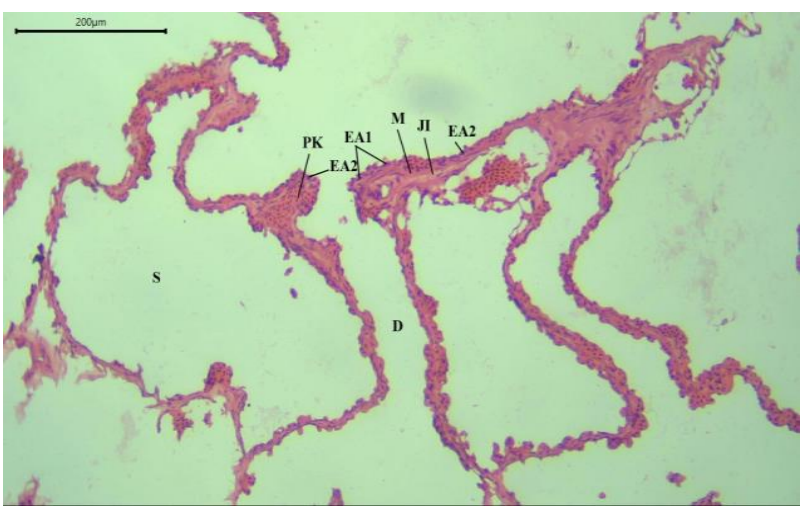

Figure 3. Structure of the lungs of water snakes (Enhydris enhydris). EA1 = type 1 alveoli epithelial cells, EA2 = type 2 alveoli epithelial cells, JI = connective tissue, $\mathrm{M}=$ Muskulus, $\mathrm{PK}=$ capillary vessels. Magnification of $100 \mathrm{X}$.

The alveoli group that surrounds and empties into the alveolar duct is also called the alveolar sac. The alveolar sac is also one part of respiration. The alveolar sac has the function and similarity of structure to the alveolar duct. If the alveolar duct is related to the alveolar sacs, the alveolar sac is related to the alveoli. From the observations found a similarity in the histological structure of the alveolar sac with the alveolar duct.

Alveoli are evaginations or outer sacs of the bronchial respiratory, alveolar ducts, and alveolar cusps, terminal ends of the alveolar ducts. Alveoli is a place where gas exchange occurs in the lungs. Respiration only occurs in the alveoli because the barrier between the air entering the alveoli and venous blood in the capillaries is very thin [11]. This ultra-thin barrier facilitates the release of carbon dioxide and efficient absorption of oxygen by the continuous circulation of erythrocytes through capillaries. Alveoli are the last branches of the bronchi after small airways called terminal bronchioles. The anatomic boundary that separates the gas exchange region from the conduit of air is called the bronchoalveolar junction [13]. From the observations of the alveoli it is seen that it is covered by a layer of epithelial alveolar epithelial cells or type 1 alveolar cell (Figure 4).

Respiratory membrane or interalveolar septa in alveoli is generally coated by simple epithelial cells or type 1 alveoli cells. Other cells contained in the respiratory membrane are alveoli septal cells or surfactant cells which are often called type 2 alveoli cells [14]. From observations other than type 1 and 2 alveoli epithelial cells found in alveoli there are also collagen connective tissue, smooth muscle bundles and the presence of blood vessel capillaries. In the interalveolar septum, there are capillaries of blood vessels, muscle bundles, and alveolar cells. This is in accordance with what was reported by Mania [7] from the results of his research on black mamba snakes and research conducted by Peixoto et al. [6] from the results of his research on Iguana iguana. Bronchial cartilage, smooth muscle, and other connective tissue originating from the mesenchyme during the embryonal period [15]. Capillaries of blood vessels and alveolar cells are found along the interalveolar septum, while the muscle bundles are only at the end of the interalveolar 
septum. Besides that, in the interalveolar septa, there are also alveolar macrophage cells called brush cells 11].

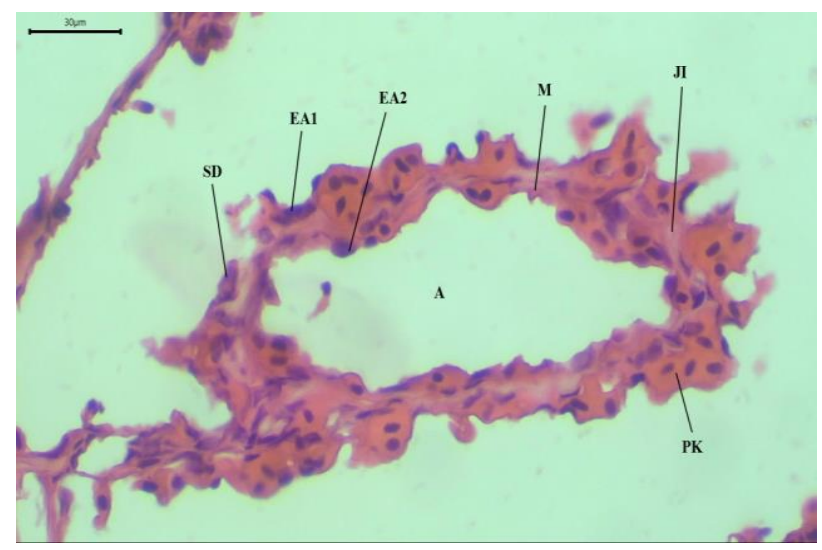

Figure 4. Alveoli structure in the lungs of water snakes (Enhydris enhydris). $\mathrm{A}=$ Alveoli, EA $1=$ type 1 alveoli epithelial cells, $\mathrm{EA} 2=$ type 2 epithelial cells, $\mathrm{M}=$ muscle, $\mathrm{JI}=$ connective tissue, $\mathrm{PK}=$ capillary vessels, $\mathrm{SD}=$ dust cells. Magnification of $400 \mathrm{X}$.

Macrophages alveoli or dust cells are monocytes that have entered the connective tissue of the lungs and alveoli [11]. Dust cells or pulmonary alveolar macrophages are not part of the alveoli wall but free cells that migrate above the lumen surface. In the pulmonary alveolar macrophage lumen exposed directly to dust or bacteria that escaped the mucous sheet in the proximal part of the airway [12]. The main function of this dust cell is to clean the alveoli of incoming microorganisms and inhaled particles by the mechanism of phagocytosis [16].

\section{Conclusion}

Based on the results of the study, it can be concluded that the histological structure of the water snake (Enhydris enhydris) lung is different from the histological structure of the reptile lungs in general. The reptile lungs generally consist of the trachea, bronchi, bronchioles, terminal bronchioles, respiratory bronchioles, alveolar ducts, alveolar saucuses, and alveoli, while the water snake lungs (Enhydris enhydris) consist only of alveolar ducts, alveolar ducts, alveolar saucuses, and alveoli, whereas water snake lungs (Enhydris enhydris) consist only of alveolar ducts, alveolar sacs, alveolar saucuses, and alveoli, whereas the water snake lungs (Enhydris enhydris) consist only of alveolar ducts, alveolar sacs, alveolar saucuses, and alveoli, whereas the water snake lungs (Enhydris enhydris) consist only of alveolar ducts, alveolar sacs, alveolar sacs, and alveoli. and the presence of air sacs at the ends of the lungs. Every part of the water snake's lungs (Enhydris enhydris) has the same arrangement as a part of the lungs in general.

\section{References}

1. Budaarsa K : Nama-Nama Latin Hewan. IPB Press, Bali. 2011.

2. Radiopoetro : Zoologi. Erlangga, Jakarta. 1968.

3. Amri K, Sihoming $\mathrm{T}$ : Mengenal dan Mengendalika Predator Benih Ikan. Gramedia Pustaka, Yogyakarta. 2008.

4. Stuebing RBInger R.F :. A Field Guide to The Snakes of Borneo. Nat. Hist. Publ. (Borneo). 1999: 93-94.

5. Sonjaya H: Dasar Fisiologi Ternak. IPB Press, Bogor. 2012.

6. Peixoto D, Klein W, Abe AS, et al. : Functional Morphology of The Lungs of The Green Iguana Iguana, In Relation of Body Mass (Squama: Reptilia). Vertebrate Zoology Senckenberg. 2018 ; 68(1): 65-82.

7. Mania JN : The morphology of the lung of the black mamba Dendroaspis polylepis (Reptilian : Ophidia: Elapidae). A scanning and transmission electron microscopic strudy. J. Anat. 1989; 167 : 31-46.

8. Aufa A : Kajian Anatomi Perbandingan Organ Pernafasan Ular Semiakuatik dan Ular Darat. Skripsi Program Studi Biologi Fakultas Sain dan Teknologi Universitas Islam Negri Sunan Kalijaga. 2013.

9. Bacha WJ, Bacha LM : Color Atlas of Veterinary Histology Second Edition. Lippincott Williams \& Wilkins, USA. 2000.

10. Surya R: Mengenal Gelembung Renang (Swim Blader) Pada Ikan. 2013. http://www.bibitikan.net/mengenal-gelembungrenang-swim-blader-pada-ikan/. 6 Juni 2019.

11. Eroschenko VP: Atlas Histologi Difore dengan Korelasi Fungsional. EGC, Jakarta. 2010.

12. Fawcett DW : Buku Ajar Histologi Edisi 12. EGC, Jakarta. 2002.

13. Logan CY, Desai TJ: Keeping It Together: Pulmonary Alveoli Are Maintained By A Hierarchy of Cellular Programs. Bioessays. 2015 ; 37(9): 1028-1037.

14. Muttaqin A : Buku Ajar Asuhan Keperawatan Klien Dengan Gangguan Sistem Pernafasan . Salemba Medika, Makassar. 2008.

15. Bustamante-Marin XM, Ostrowski LE : Cilia and mucociliary clearance. Cold Spring Harb Perspect Boil. 2018 ; 9(4):1-24.

16. Reid L, Meyrick B, Antony VB, et al.: The Mysterious Pulmonary Brush Cell. American Journal of Respiratory And Critical Care Medicine. 2005 ; 172(1):136-139. 